see 1TP3-05

\section{P-056＼cjkstart新規発光共役高分子による新規インスリンフィラメントの細胞毒 性と内部構造解明}

Cell toxicity and inner structure analysis of novel insulin filaments using novel luminescent conjugate polymers

Takahiro Kobayashi (1), Tamotsu Zako (2), Masafumi Sakono (2), Mikael Lindgren (3) Peter Nilsson (4), Per Hammarstrom (4), Mizuo Maeda (1) ((I) Front.Sci., Univ. Tokyo: (2) RIKEN: (3) Dept. Phys., The Norwegian Univ.: (4) Dept. Chem., Linkoping Univ.)

\section{see 1TP3-04}

\section{P-057 キャピラリー内トラップによるー分子の長時間観察 : 蛋白質の折 り畳みへの応用}

Long-time observation of a single molecule trapped in a capillary cell: application for protein folding

Kiyoto Kamagata (1), Yuji Goto (2), Satoshi Takahashi (3) ((1) Institute of Multidisciplinary Research for Advanced Materials, Tohoku University: (2) Institute for Protein Research, Osaka University: (3) Institute of Multidisciplinary Research for Advanced Materials, Tohoku University; CREST, JST)

see $1 \mathrm{YP} 1-02$

\section{P-058 ポリグルタミン病の新たな分子病理メカニズムータンパク質線維} の構造伝播による発症制御の可能性

Cross-seeding fibrillation of $\mathrm{Q} / \mathrm{N}$-rich proteins offers new pathomechanism of polyglutamine diseases

Yoshiaki Furukawa (1), Kumi Kaneko (1), Masaru Kurosawa (1), Gen Matsumoto (1) Nobuyuki Nukina (1) ((1) RIKEN, Brain Science Institute)

$$
\text { see 1YP1-08 }
$$

\section{P-059 蛋白質の体積摇らぎ動力学に対する圧力効果}

Effects of Pressure on Volume-Fluctuation Dynamics of Proteins

Kunitsugu Soda (1), Yudai Shimbo (2), Yasutaka Seki (2), Makoto Taiji (1) ((I) Computational Systems Biology Group, RIKEN: (2) Dept. Bioeng., Nagaoka Univ. Technol.)

$$
\text { see 1TP3-06 }
$$

\section{P-060 青色光センサータンパク質フォトトロピンの光反応に対する} Crowding 効果

The effect of macromolecular crowding on photoreaction of a blue light sensor protein; phototropin

Tsuguyoshi Toyooka (1), Yuusuke Nakasone (1), Kazunori Zikihara (2), Tooru Tokutom (2), Masahide Terazima (1) ((1) Department of Chemistry, Graduate School of Science, Kyoto University.: (2) Research Institute for Advanced Science and Technology, Department of Biological Science, Graduate School of Science, Osaka Prefecture University.)

A characteristic of interiors of living cells is high concentrations of macromolecules. Such media are termed 'crowding condition'. Under this condition, chemical reactions could be different from those occurring in a dilute solution. Here, for elucidating the photoreaction dynamics of phototropin, which is a blue light sensor of plants to regulate the phototropism, we studied the reaction in pseudo-simulated solution by dissolving Ficoll 70 (M.W. 70000) at a high concentration $(\sim 300 \mathrm{~g} / \mathrm{L})$. Phototropin has LOV1, LOV2, and kinase domains and the reaction dynamics has been investigated previously by the timeresolved transient grating (TG) method in a dilute solution. It showed that a part of $\alpha$-helix is unfolded after the photoexcitation of phot 1 LOV2 and Phot 1 LOV2-linker (linker is a domain between LOV2 and kinase domains) sample and these reactions should be closely related with the biological function of phototropin. It is interesting to examine the crowding effect on this reaction to elucidate the reaction in living cells. With increasing the concentration of Ficoll, the intensity of the TG signal of phot1 LOV2-linker sample decreased drastically. This change was explained by the decrease of the reaction quantum yield and the decrease of the diffusion coefficient change under the crowding condition. We also observed that the association state of phot1 LOV2 is sensitively affected by the crowding. These crowding effects will be discussed.

\section{P-061 光センサータンパク質 TePixD の反応ダイナミクスへの圧力効果}

Pressure effects on reaction dynamics of a photosensor protein TePixD

Kunisato Kuroi (1), Keisuke Tanaka (1), Yusuke Nakasone (1), Kouji Okajima (2), Masahiko Ikeuchi (3), Satoru Tokutomi (4), Masahide Terazima (1) ((1) Department of Chemistry, Graduate School of Science, Kyoto University: (2) Department of Life Sciences (Biology), Graduate School of Arts and Sciences, The University of Tokyo. Research Institute for Advanced Science and Technology, Department of Biological Science, Graduate School of Science, Osaka Prefecture University: (3) Department of Life Sciences (Biology), Graduate School of Arts and Sciences, The University of Tokyo: (4) Research Institute for Advanced Science and Technology, Department of Biological Science, Graduate School of Science, Osaka Prefecture University)

Fluctuation during protein reaction plays an important role in biological function. However, it is very difficult to detect such fluctuation experimentally. Fluctuation is directly related to thermodynamical parameters. For example, isothermal compressibility is defined as pressure differentiation of volume change, and this parameter determines volume fluctuation. The time-resolved transient grating (TG) technique is one of powerful methods to measure thermodynamical parameters and diffusion coefficient (D) of short-lived intermediate in photosensor protein reactions. In this study, we applied the TG technique to photoreaction dynamics of a photosensor protein TePixD under various pressures up to $400 \mathrm{MPa}$. TePixD is a blue light sensor protein with a BLUF domain and forms a unique decamer in crystal. Furthermore, in solution, TePixD is in equilibrium between the decamer and pentamer. The TG signal of TePixD at 1 atm has revealed that TePixD shows volume expansion and D-change of the decamer during the photoreaction. Interestingly, the diffusion signal intensity and profile of TePixD were found to depend on the pressure dramatically. This dependence is considered to be pressure effect on the equilibrium. We will also report pressure dependence of volume change and enthalpy change, and discuss the relation between fluctuation and function of this photosensor protein.

\section{P-062 線形応答自由エネルギー法を用いた Chalcone Isomerase による 触媒反応の理論的研究}

Theoretical Analysis of Chalcone Isomerase Catalyzed Reaction Using Linear Response Free Energy Method

Ryoichi Kida (1), Masahiro Higashi (2), Shigehiko Hayashi (1), Shigeki Kato (1) ((1) Graduate School of Science Kyoto University: (2) Institute of Molecular Science)

For studying chemical reactions in solution and enzymes, we often use combined quantum mechanical/molecular mechanical (QM/MM) methods. Since a large number of degree of freedom are involved in such reaction processes, free energy surfaces instead of potential energy surfaces are necessary to be examined. Several methods based on QM/MM techniques have been developed to calculate free energy profiles of chemical reactions.

We employ QM/MM Linear Response Free Energy (LRFE) method, proposed by Higashi et al, which makes it possible to calculate free energy and free energy gradients of the systems. We have studied chalcone isomerase catalyzed reaction, using this method. Chalcone isomerase catalyzes transformation of chalcones to flavanons. Some reaction paths have been proposed in earlier studies. We optimized the geometry of chalcone and some neighbour residues, and calculated free energy profile along the reaction paths.

To analyze the catalytic effects, we defined and calculated site dipole constant based on the generalized Born formula using site electrostatic potential obtained from LRFE.

This research was supported in part by the Global COE Program "International Center for Integrated Research and Advanced Education in Materials Science" (No.B-024) of the Ministry of Education, Culture, Sports, Science and Technology (MEXT) of Japan, administrated by the Japan Society for the Promotion of Science

\section{P-063 フラビン依存性オキシダーゼが示す非ミカエリス -メンテン型反 応機構の理論的解析}

Theoretical analysis of the reaction mechanism of non-Michaelis kinetics of flavin-dependent oxidases

Tetsuo Ishida (1), Atsushi Yamamoto (1), Hiroyuki Tanaka (1), Kihachiro Horiike (1) ((1) Shiga University of Medical Science)

Flavin-dependent oxidases frequently exhibit non-Michaelis kinetics. For instance, monoamine oxidase A and L-aspartate oxidase show strong substrate activation. Substantial levels of substrate inhibition are more often found for various oxidases (L-amino acid oxidase is a typical one). However, why flavin-depedent oxidases are prone to show substrate activation/inhibition has not been addressed systematically. Proper analysis of the kinetic data has not been carried out either. Recently, we have found that porcine D-aspartate oxidase exhibits significant substrate activation for $\mathrm{D}$-aspartate, its endogenous substrate, under physiological conditions (J. Biochem. (2007) 141, 363-376). To explain the observed substrate 